\title{
The Military and Development in Eastern Africa
}

\section{by Geoff Lamb}

Eastern Africa is not so thoroughly militarized a region as the west or north of the continent; yet four states in the area are soldier-governed (Burundi, Uganda, Sudan and Somalia), and the armed forces seem likely to play an important role in political developments in Kenya and Tanzania in the near future. An assessment of the implications of military dominance for development in the region is therefore clearly important, albeit complicated by the wide disparities between the various countries involved. But some comparisons can be made about the military governments themselves. The young military men who seized power in Burundi (1966), Sudan (May 1969), and the Somali Democratic Republic (October 1969) certainly saw themselves as the embodiment of militant nationalism, even of socialism, overcoming a discredited, corrupt and reactionary political old guard. (In Burundi, the list of obsolete institutions and personalities included the throne and its occupant). In Uganda (January 1971) on the other hand, ideological justifications were equally in evidence, but the coup-makers' position was anti-socialist if anything. While there were reasons internal to the army for the coup, it was also neatly timed to thwart President Obote's plans for implementing a "Move to the Left" and general elections under an electoral system which would have made it impossible for any MP to be elected without considerable pan-tribal support.

But new military governments, like most governments, are rarely merely what they seem to be, or at least they rarely remain so. This year, for example, has provided bloody evidence against President Micombero's claim to be anything other than the latest and most brutal weapon of the Tutsi ascendancy over Burundi's Hutu majority. If the reports of the killings which

* Geoff Lamb is an IDS Fellow. 
have continued since May this year are anywhere near the truth, the Burundi army has responded to an abortive Hutu rebellion by slaughtering most present and likely members of the emergent Hutu educated class, even down to some secondary school pupils.

In the Sudan, an attempt at a counter-coup in July 1971 also provoked bloody, though much more limited, reprisals - in this case, the government of President Jafaar el-Nimeiri took the opportunity of summarily executing the country's leading Communists, and thereafter trying to expunge the Party's influence from the national 1 ife, apparently with only limited success. Much blood has been shed in Uganda, too, where it is almost certain that some thousands of soldiers and civilians have been killed, most of them from the allegedly 'pro-Obote' Langi and Acholi tribes. Somalia, in the hands of a Marxistoriented officer group, has so far avoided bloodshed, even that of the leaders of an unsuccessful counter-coup in May 1971 .

But despite the cost in human lives which these coups d'etat brought in their wake, their significance must ultimately be evaluated in other terms as well. Military coups are the outcome of the incapacity of governing elites to cope with the problems of underdevelopment, of social and economic change and political control which confront them: the incoming officer groups are more or less explicit, after their individual fashions, about the sources of this incapacity and, by contrast, about their own determination and ability to 'do the job'. What, therefore, has changed either in development strategy pursued or development achievements since these countries have been under military rule?

On the whole, the picture is a bleak one. In Burundi, 1971 saw some improvement over the huge foreign trade deficits of earlier years, which had been running at about $\mathbf{f} 4 \mathrm{million}-$ in a country with total annual exports of $£ 5$ million! Consumer goods accounted for about 75 per cent of the import bill. But even after the improvements of 1970 and 1971 , which were exceptionally good years for coffee (the main export crop), it required heavy aid contributions from Belgium and the EEC to push the balance of payments into surplus, though with few signs of systematic curbs on consumer imports. And one of the outcomes of the butchery in 1972 is likely to be a downturn in coffee production, since thousands of Hutu peasants have been fleeing their coffee holdings at the approach of army patrols, and not returning. 
The Sudan Revolutionary Command Council had much more radical and systematic economic change in mind than president Micombero ever did. The Five Year Plan published in 1970 anticipated fundamental structural change through nationalization of foreign concerns and of the 'commanding heights' of the economy, and also an end to the old system of deficit financing and rapidly mounting public debt. The Plan, prepared with Soviet assistance, nevertheless assumed that about $60 \%$ of total investment of $\$ 385$ million over the five years would come from the private sector. The political upheavals of the ensuing two years, however, as much as the difficulty of effecting such thoroughgoing reforms, have cast doubt on the regime's continued commitment to the strategy enshrined in the Plan, let alone on its ability to implement it. Some of the nationalization measures were reversed after the defeat of the Communist-supported counter-coup in 1971, explicitly because, according to President Nimeiri, "national capitalists" had been unfairly treated in the early days of the Revolution. At the same time, the Government's internal debt has climbed

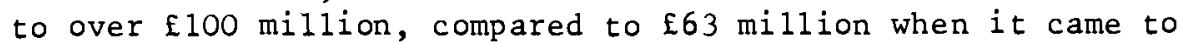
power. The indications are not particularly encouraging in an economy in which, according to the new series of national accounts, real per capita GNP probably stagnated for seven years before the Nimeiri takeover.

These disappointments are very much related to the vagaries of internal and international politics, and particularly to the great current issues in sudan politics of relations with the negro south of the country, which had up till this year been in a state of rebellion against the Arab north of the country, and of relations with the Arab world - issues which have always pulled Sudanese leaders in opposite directions. In this context of pressure from Sadat and Gaddafy to make the United Arab Republic a reality, and a fragile peace to preserve in the South, the complications of dealing with urban workers and employers, with Gezira scheme tenants, and with an intelligentsia of a highly politicised and generally radical kind, let alone with the Sudan's politico-religious Ansar and Khatmiya sects - all these pressures and conflicts have tended to lead rather swiftly to policies and political styles not too different from the bad old days of 'the politicians'.

The economic strategy of General Amin's government on its seizure of power was simplicity itself: the nationalization measures of the Obote regime were immediately reversed. Some 80 enterprises had been instructed by obote to cede 60 per 
cent of their equity to the Government, but Amin proposed that only 18 of these companies, mainly banks and insurance firms, should cede not 60 but 49 per cent to the state. Reports of 'encouraging signs' of a resumption of the flow of overseas investment capital were somewhat premature, however: foreign investors seem to have been as wary of instability and unrest under the Amin regime as they were of nationalization and 'moves to the left' under Obote. The Third Five Year Plan published last year anticipates an annual GDP growth rate of 6 per cent, necessitating total investment of Uganda $£ 350$ mil. over the plan period, some 60 per cent of it from local sources. The omens are not particularly good. Development expenditure in 1971 was reduced by some 50 per cent from its 1970 level to Uganda $\{33 \mathrm{million}$, and about 60 per cent of an estimated Uganda 14 million budgetary deficit was due to be financed by an increase in the issue of money. At the same time, the preoccupation of the regime with trying to placate or control restive and disparate domestic groups has made for an extremely unpredictable political environment for making economic decisions. Thus the recent decision that all noncitizen Asians are to be expelled within a matter of months may indeed have been taken, as has been suggested, to create employment and spoils for a rising and restive petty bourgeoisie. It is clearly also going to have a sharp impact on domestic (and maybe foreign) investment, and on illegal capital flight. But perhaps it is useless to evaluate General Amin's Uganda in these terms. Certainly the General, who likes to refer to various sections of Ugandan society as "the units" (i.e. of an army), seems primarily concerned with other things, of which just staying afloat politically is currently probably uppermost (there have been at least one coup attempt and incessant rumours of others in his 18 -odd months in power).

Somalia is by far the most backward of the four countries. Sixty per cent of its estimated 3 million people are nomadic cattle, camel and goat keepers, and a further 20 per cent are settled herdsmen and farmers. Per capita income is 455 shillings a year (17.4 Somali shillings to the $f$ ), and opportunities for non-agricultural employment are minuscule: secondary school graduates in particular are having difficulty finding jobs. There are only two perennial rivers in the country, and the problems of drought have been exacerbated by Ethiopian obstruction of Somali attempts to use traditional and vital grazing grounds which were ceded to Ethiopia before independence in 1960 - obstruction which has led to armed clashes on several occasions. 
The development programme for $1971-73$ set out by the Supreme Revolutionary Council is therefore modest. Though its explicit philosophy is socialist and Marxist, the programme recognizes that the poverty of the country necessitates not only the continuation of the mixed economy, but also an initial powerful emphasis on rural improvements, communications and institutional development, rather than on attempts at socialist transformation. Thus the programme concentrates on improvement of basic services to livestock and agriculture, especially in the fields of veterinary services, water provision, range management and marketing, while efforts are also being made through state corporations to expand the export of meat rather than livestock (which at present accounts for over 50 per cent of total exports of 224 million shillings, and nearly al 1 goes to Saudi Arabia). A National Banana Agency has been set up to rationalize production and marketing of the second biggest export, under severe pressure from the closure of the Suez Canal and the loss of preferences in the Italian market.

But some of the most interesting aspects of the Somali rulers' development ideas are those concerning social change and politics. Considerable attention is paid to "enlightening the masses to the realities and needs of national development through political orientation and proper national guidance"1, and all civil servants have been required to undergo fairly arduous political education and indoctrination courses (sometimes as part of the process of weeding out anti-regime elements), as do army officers. A new scheme of compulsory National Service will involve young school leavers in a similar activity for one year, followed by a further year engaged in teaching or other 'developmental' activities.

There is also an explicit but necessarily cautious commitment to combat the negative effects of nomadism and tribalism. Thus an important part of the government"s well-digging programme is to ensure that the wells are kept open to all tribes or clans in the area, and that the opportunity is taken to explain government policies and 'make revolutionary propaganda' when pastoralists arrive with their herds (shades of the Machine and Tractor Stations). Administrative decentra1ization, the promotion of self-help schemes and in particular the establishment of rural co-operatives are seen as integral to the effort to encourage communal participation and co-

1 DeveZopment Programme 1971-73, chapter I, Ministry of Planning and Coordination, Mogadishu, 1971. 
operation in the development process, while the Department of Labour in particular sees a major part of its task as being concerned not only with wider distribution of wealth and employment opportunities, but with a deeper understanding of the consequences of internal migration and nomadism, and of the possibilities of integrating the segmented and isolated nomad groups into the 'human resource planning process'.

But President Syad Barre and his Council have, in a sense, only begun to expose to themselves the central problems of military rule. The new Somali rulers have had several advantages - in the continued and expanded economic and political support of the Soviet Union, in the fact that the army officer corps, and particularly the young officers, form a fairly coherent Marxist political base (an attempt by two Revolutionary Council members to stage a counter-coup in May last year with the assistance of some members of the old regime and its supporters was apparently easily crushed without generating significant differences within the armed forces). But, like other much worse military regimes, the Somali government has yet to overcome the major obstacles of establishing a secure political base, and (a related problem) of being able to cope with the bureaucracy.

In a sense, what this means is that armies never really stand 'outside' society: their political functions, their recruitment and career patterns, their organizational structures, all reflect different aspects of the societies of which they are part. Thus, for example, in both the Sudan and Somalia the young officers have tended to be the cutting edge of the nationalist educated elite. In both countries, the same combination of widespread nationalist sentiment, a corrupt ruling class and thrusting petty bourgeois ambition which fuelled the Egyptian Free Officers movement was present. In the Somali case, diplomatic ties forged with the Soviet Union in the early years of independence, and consequent defence agreements, helped to give a further leftward impetus to army politics, whereas in the Sudan it was the intelligentsia outside rather than within the army which espoused Marxism. In Uganda or Burundi, by contrast, tribal origin counted for far more in the military context than did ideology or class origin, and one effect of the military seizure of power was to make the ethnic composition of the armed forces of immediate, and ultimately in both cases tragic, importance.

Once in power, in other words, military leaderships tend to "soak up social conflict like a sponge", in Ruth First's 
memorable phrase. ${ }^{1}$ That is, the military organization immediately becomes vulnerable to social and political pressures from which it was hitherto to some extent protected, and is required to operate under conditions and for purposes for which it was not designed. In this situation of a leadership ill equipped to deal with policy-making and politics, an immediate and at times obviously dependent alliance with the established bureaucracy often occurs. At the same time, the pivotal position of the bureaucracy is enhanced by the characteristic difficulty of military regimes in establishing anything approaching an organised popular base, or even an alternative means of communication with the population. General Amin's barrack-room populist style and General Mobutu Sese Seko's 'authenticity' campaign in Zaire may represent one kind of attempt to establish a non-bureaucratic, nonmilitary following of sorts. Another classic pattern is for the military dictator to confer on himself, usually through election or referendum, a certain civilian legitimacy as President, as President Nimeiri has now done, and to construct a national political organization of sorts.

It seems that this last is the most difficult task of a11, and yet clearly an essential one if there is to be any hope of military governments being transformed (if in the particular case they contain any such potential) into responsive and effective governments, capable of formulating implementing development policies relevant to the 1 ives of most of their people. There are, heaven knows, plenty of examples of the other, pathological kind, of corrupt and ineffectual African military regimes, whose brutality may be tempered by inefficiency in the traditional manner, but whose numbing effect on the struggle to escape from poverty is hardly tempered at all.

The Somali regime is particularly interesting in this context, both for its efforts to establish political and ideological bridgeheads among the people, and for its attempts to re-make the country's civil service in its own image by the use of orientation courses and the like. (A possible sign that the regime is on the right path is the fact that Somali civil servants have had to be told several times that they are wrong to suppose that the courses are designed to 'punish' them for

1 Ruth First, The Barrel of a Gun: Politiaal Power in Africa and the Coup d'Etat, Allen Lane, the Penguin Press, 1970; Penguin Books, 1972 . 
past sins.) In these efforts, one may note, the Somali leaders are beginning to confront problems very similar to those encountered in a rather different political context by the Tanzanians - i.e. those of effecting radical changes in economy and society, changes which will very quickly raise questions about the power and privileges, and even the way of life, of the educated elite in charge of the instruments of policy. It may thus be in the capacity to transform itself rather than others that the central dilemma of the genuinely reformist or revolutionary military governments resides. 